\title{
Pemberdayaan Masyarakat dengan Mengenalkan Bahasa Mandarin dan Budaya Tiongkok di Era New Normal pada Anak-Anak Taman Baca Masyarakat (TBM) Gumala Kreatif
}

\author{
Tri Budianingsih ${ }^{1}$, Berillya Imandika $^{1^{*}}$ \\ ${ }^{1}$ Program Studi Bahasa Mandarin dan Kebudayaan Tiongkok, Fakultas Ilmu pengetahuan \\ Budaya,Universitas Al Azhar Indonesia, Jalan Sisingamangaraja, Kebayoran Baru, Jakarta 12110 \\ Email Penulis Korespodensi:berillyai@gmail.com
}

\begin{abstract}
Student study service from home is a compulsory course at the University of Al Azhar Indonesia. This activity directing students to do such community service activity based on their major fields in their hometown area, to provide benefits according to their respective fields. Based on the survey, children's ability in the Guguk Malintang sub-district about foreign languages is not well developed, especially in the Chinese language. Moreover, the people's knowledge about China is also lacking. In the Guguk Malintang sub-district, there is an activity called Gumala Kreatif, which is a public organization engaged in literacy, economy, culture, and customs. This organization consists of children, adolescents, and adults. Children members gather twice a week, on Friday afternoon and Sunday afternoon for traditional dance and randai practice. On this occasion, the author tries to solve that problem by introducing the basic Chinese language and culture to these children. The method used is to teach and discuss directly Chinese language material and basic Chinese culture with the students. In this activity, the author will cooperate with the Guguk Malintang villagers, especially the management of the TBM Gumala Kreatif to implement the learning method. By learning the Chinese language and culture, children can recognize foreign languages and cultures from an early age and open their horizons about the outside world. The results obtained are as many as $85 \%$ of participants can understand the material well, and $75 \%$ of participants can repeat the material smoothly. A high enthusiasm from the participants and activists makes this student study service activity run smoothly.
\end{abstract}

\section{Keywords: Student study service, community service activity, Chinese language and culture}

\begin{abstract}
Abstrak
Kegiatan Kuliah Kerja Nyata Dari Rumah (KKN-DR) merupakan salah satu mata kuliah wajib di Universitas Al Azhar Indonesia. Kegiatan ini mengarahkan para mahasiswa untuk melakukan kegiatan pengabdian masyarakat sesuai keahlian program studi di lingkungan tempat tinggal masing-masing dengan tujuan untuk memberikan manfaat sesuai dengan bidangnya masing-masing. Berdasarkan survey yang telah penulis lakukan, ditemukan sebuah masalah yaitu kemampuan bahasa asing anakanak di Kelurahan Guguk Malintang kurang berkembang dengan baik, terutama bahasa Mandarin, selain itu pengetahuan masyarakat tentang Tiongkok juga masih kurang. Di masyarakat Guguk Malintang terdapat suatu kegiatan Taman Baca Masyarakat (TBM) Gumala Kreatif, yaitu organisasi masyarakat yang bergerak di bidang literasi, budaya, ekonomi dan adat. Organisasi ini beranggotakan anak-anak, remaja dan orang dewasa. Anak-anak Gumala Kreatif mengadakan pertemuan dua kali seminggu, yaitu pada Jum'at siang dan Minggu siang untuk melakukan latihan tari tradisional dan randai. Di kegiatan inilah penulis mencoba menyelesaikan masalah tersebut dengan memperkenalkan bahasa Mandarin dan budaya Tiongkok dasar kepada anak-anak di TBM Gumala Kreatif. Metode yang digunakan adalah dengan memberikan pengajaran dan berdiskusi secara langsung mengenai materi bahasa Mandarin dan budaya Tiongkok dasar. Pada kegiatan KKN-DR ini penulis akan bekerja sama dengan kelurahan Guguk Malintang khususnya pengurus TBM Gumala Kreatif untuk melaksanakan metode pembelajaran tersebut. Dengan demikian, anak-anak dapat mengenal bahasa dan kebudayaan
\end{abstract}


asing sejak dini dan dapat membuka wawasan mereka tentang dunia luar. Hasil yang didapatkan adalah sebanyak $85 \%$ peserta dapat memahami materi dengan baik, dan $75 \%$ peserta mampu mengulangi materi dengan lancar. Antusiasme yang tinggi dari para peserta dan pegiat membuat kegiatan KKN-DR ini berjalan dengan lancar.

Kata kunci: Kuliah kerja nyata, pengabdian masyarakat, Bahasa Mandarin dan Budaya Tiongkok

\section{PENDAhULUAN}

Pengabdian masyarakat merupakan salah satu dari tridharma perguruan tinggi. Setelah belajar di institusinya, mahasiswa dituntut untuk terjun dan memberikan manfaat ke masyarakat. Pengabdian ini merupakan bukti nyata kebermanfaatan mahasiswa setelah menempuh mendidikan dan merupakan bukti nyata kontribusi mahasiswa ke masyarakat.

Di sebuah kelurahan yang bernama Guguk Malintang yang terletak di Kota Padang Panjang Provinsi Sumatera Barat, terdapat penduduk berjumlah 6.584 jiwa (Dinas Kependudukan dan Pencatatan Sipil Kota Padang Panjang, 2020). Kegiatan masyarakat di kelurahan ini terdiri dari $35 \%$ berdagang, 35\% campuran (bertani, perikanan, jasa dll), dan $30 \%$ Aparatur Sipil Negara (ASN).

Taman Baca Masyarakat (TBM) Gumala Kreatif adalah sebuah kegiatan masyarakat di kelurahan Guguk Malintang, kota Padang Panjang, Sumatera Barat. Kegiatan ini diadakan rutin dua kali seminggu, yaitu pada hari Jum'at dan Minggu siang. Kegiatan ini mulai diadakan sejak tahun 2019 dan mencakup berbagai bidang, yaitu bidang literasi dan keagamaan (tahfidz Al-Qur'an, membaca dan mengambil kesimpulan), bidang budaya (Randai, tari tradisional, permainan alat musik tradisional), ekonomi (batik, sulaman, rajutan, pemanfaatan limbah rumah tangga), dan bidang adat (manyerak bareh kunik). Peserta yang ikut pun tidak terbatas umur, mulai dari anak-anak hingga orang tua. Peserta Gumala Kreatif selama satu tahun belakangan ini sudah mengikuti berbagai kegiatan di tingkat kota, bahkan pernah menjadi juara 1 pada lomba literasi berbasis inklusif se-kota Padang Panjang, dan meraih juara harapan 1 tingkat Provinsi Sumatera Barat. Anggota TBM Gumala Kreatif ini berkisar sekitar 15 orang anak-anak tingkat SD dan SMP, dan 8 orang ibuibu. Namun anggota ini tidak selalu tetap karena meninjau bahwa kegiatan ini adalah kegiatan suka rela, dan tidak adanya kewajiban bagi masyarakat untuk mengikuti kegiatan ini.

Dalam masa pandemi covid-19 ini, banyak kegiatan yang terhenti, dikarenakan keharusan untuk mematuhi protokol kesehatan dengan mengurangi kegiatan luar ruangan dan kegiatan yang melibatkan orang banyak. Hal ini membuat para pembuat kebijakan merubah cara pelayanan kepada masyarakat. Begitu pula dengan kegiatan di TBM Gumala Kreatif, kegiatan yang mulai aktif semenjak bulan Oktober tahun 2019 ini terpaksa berkurang kuantitas pertemuannya semenjak mewabahnya virus covid-19 di indonesia, yaitu sekitar Maret 2020. Sehingga masyarakat merasa jenuh dan kurang produktif selama masa pandemi. Semenjak diberlakukannya new normal oleh pemerintah, kegiatan TBM Gumala Kreatif mulai diadakan kembali, namun pesertanya jauh berkurang dari sebelumnya, yaitu hanya kurang lebih setengahnya saja. Kegiatan yang dilaksanakan juga tidak sebanyak biasanya, yaitu hanya mengaji Al-Qur'an, latihan tari tradisional, dan latihan randai. Hal ini membuat pengurus TBM Gumala Kreatif merasa bahwa dibutuhkan kegiatan lain yang dapat meningatkan produktivitas dan tentunya menambah pengetahuan para peserta.

Sebagai mahasiswa program studi Bahasa Mandarin dan Kebudayaan Tiongkok di Universitas Al Azhar Indonesia, tentunya penulis juga ingin memberikan manfaat yang sejalan dengan program studi penulis kepada masyarakat sekitar. Selain itu fakta di lapangan menunjukkan bahwa kurangnya minat dan kesempatan masyarakat di kelurahan Guguk Malintang untuk mempelajari bahasa asing khususnya bahasa Mandarin. Oleh karena itu, untuk membantu pengurus TBM Gumala Kreatif dan perangkat kelurahan, serta untuk membagikan ilmu kepada anak-anak di daerah setempat, penulis bermaksud untuk memberikan pembelajaran Bahasa Mandarin dan budaya Tiongkok dasar kepada anak-anak di TBM Gumala Kreatif. Pembelajaran ini diharapkan dapat menjadi motivasi dan bekal bagi anak- 
anak tersebut dalam pengembangan ilmu dan untuk pengetahuan mereka. Kemampuan bahasa Mandarin yang dipelajari juga dapat menjadi nilai tambah bagi mereka saat belajar di bangku sekolah maupun untuk karir mereka di masa depan nanti.

Melihat kemajuan Tiongkok yang semakin menjadi negara yang memiliki kekuatan besar, bahasa Mandarin semakin layak untuk dipelajari. Menurut Fu (2014:114), bahasa Mandarin adalah bahasa yang jumlah penuturnya paling banyak di dunia, dan telah diakui sebagai salah satu dari enam bahasa resmi yang digunakan oleh Perserikatan BangsaBangsa (PBB). Maka dari itu mempelajari bahasa Mandarin adalah salah satu hal penting yang dapat memengaruhi kesuksesan di masa depan.

Menurut Sutami (2016:216), pengajaran Bahasa Mandarin bertujuan memajukan bangsa dalam menghadapi persaingan dunia yang semakin ketat. Jadi, kepentingan mengajarkan dan mempelajari Bahasa Mandarin adalah untuk kepentingan nasional Negara Kesatuan Republik Indonesia, bukan untuk kepentingan golongan keturunan Tionghoa seperti masa lampau.

Menurut Yi Ying; dkk. (2013) sekarang sangat penting bagi generasi muda Indonesia untuk memiliki bahasa asing kedua selain Bahasa Inggris, yaitu bahasa Mandarin. Di era globalisasi, masyarakat tidak hanya akan bertemu orang-orang dari belahan dunia yang berbahasa Inggris saja. Mereka juga akan bertemu orang-orang dari Tiongkok yang berbahasa Mandarin, karena penduduk Tiongkok adalah $20 \%$ dari penduduk dunia.

Penulis juga berharap dengan melaksanakan kegiatan KKN ini, penulis dapat mengenal lebih dalam kehidupan di sekitar tempat tinggal penulis. Dengan bersosialisasi dengan masyarakat, memahami situasi dan kondisi sosio-ekonomi warga kelurahan, ritme hidup masyarakat, dan pola pikir masyarakat sekitar. Dengan demikian, sebagai pembelajar ilmu humaniora yang mempelajari ilmu budaya masyarakat, khususnya ilmu tentang Tiongok, penulis dapat membandingkan kehidupan masyarakat di dua lingkungan yang berbeda. Menelaah berbagai aspek yang dapat mempengaruhi kualitas hidup masyarakat dan menemukan hal positif yang dapat diserap dari masing-masing masyarakat dengan kebudayaan yang berbeda. Penulis juga diharapkan dapat memberikan masukan dan kontribusi kepada warga sekitar berkaitan dengan kemampuan dan pengetahuan yang telah penulis dapatkan selama belajar di bangku perkuliahan.

Tujuan dari pelaksanaan kegiatan ini adalah untuk memperkenalkan pengetahuan dasar berbahasa asing Mandarin dan menimbulkan kesadaran anak-anak akan pentingnya belajar bahasa asing di masa sekarang ini.

\section{METODE}

Metode yang digunakan untuk mencapai tujuan pelaksanaan kegiatan KKN-DR ini adalah dengan memberikan pengajaran bahasa Mandarin dasar secara langsung dan melakukan diskusi dengan para peserta ajar mengenai topik yang relevan.

Menurut Rolly Yesputra dalam artikelnya yang berjudul Pengabdian kepada Masyarakat (2015), ada lima pendekatan yang dapat digunakan dalam melakukan pengabdian kepada masyarakat, yaitu community development, persuasif, edukatif, partisipatif, dan normatif. Pendekatan yang penulis lakukan dalam melaksanakan kegiatan KKN DR ini adalah edukatif, karena dalam program yang penulis lakukan mengandung unsur pendidikan dan mendinamisasikan masyarakat menuju sebuah kemajuan yang diharapkan, yaitu bertambahnya pengetahuan peserta mengenai bahasa Mandarin dasar.

Persiapan yang penulis lakukan pertama kali adalah mengamati lingkungan sekitar dengan bertanya kepada ketua RT setempat, petugas kelurahan, dan pengurus TBM Gumala Kreatif. Setelah mendapatkan informasi penulis mulai menyusun kurikulum pembelajaran dengan metode pengajaran langsung mengenai materi bahasa Mandarin dasar, yaitu dengan standar HSK 1 dan HSKK tingkat dasar. Pertemuan dilaksanakan dua minggu sekali, yaitu setiap hari Jum'at siang dan Minggu siang dalam kurun waktu satu bulan. Sebelum kegiatan berlangsung penulis melakukan tes awal (pre test) untuk mengetahui apakah benar para peserta tidak memiliki kemampuan bahasa Mandarin dan pengetahuan budaya Tiongkok sama sekali. Selama mengajar, selain anak-anak peserta ajar, juga hadir pengurus TBM Gumala Kreatif, ketua RT dan pengurus kelurahan. Selain itu penulis juga beberapa kali melaksanakan bimbingan dan diskusi dengan dosen pendamping lapangan mengenai hambatan-hambatan yang ditemui. Setelah 
selesai melaksanakan seluruh rangkaian pembelajaran, penulis melaksanakan tes akhir (post test) terhadap para peserta untuk mengukur kemampuan mereka. Peserta mengaku setelah mengikuti kegiatan pembelajaran, pengetahuannya mengenai Tiongkok menjadi semakin terbuka, bahkan ada juga yang tertarik untuk mempelajari Bahasa Mandarin lebih lanjut. Namun setelah kegiatan KKN-DR berakhir, peserta tidak lagi melanjutkan pembelajaran Bahasa Mandarin seperti biasa karena sedang fokus mempersiapkan lomba Randai tingkat kota.

\section{Waktu dan Tempat Pelaksanaan}

Kegiatan KKN-DR ini dilakukan di Kelurahan Guguk Malintang, tepatnya di salah satu rumah warga yang juga merupakan pusat kegiatan TBM Gumala Kreatif. Kegiatan dilakukan sebanyak 5 kali pertemuan selama bulan Februari 2021.

\section{Peserta kegiatan KKN-DR:}

Peserta dari kegiatan belajar Bahasa Mandarin dan Budaya Tiongkok dasar KKNDR ini adalah anak-anak usia sekolah dasar di TBM Gumala Kreatif. Peserta yang rutin mengikuti pembelajaran berjumlah 10 orang. Berdasarkan pengamatan berupa wawancara langsung, didapati fakta bahwa mereka belum pernah mempelajari bahasa Mandarin dan budaya Tiongkok sebelumnya sehingga belum mengenal negara Tiongkok dengan baik. Hal ini didapatkan dari penulis menanyakan hal yang sangat dasar dalam bahasa Mandarin, seperti “你好 $n \check{I} h \check{a} o$ ” (halo), “谢谢 xièxie ” (terima kasih), “我叫 wǒ jiào” (nama saya), “再见 $z$ àiji àn” (selamat tinggal), dan “对不起 duìbùq I I ” (maaf), mereka tidak bisa menjawabnya sama sekali. Hal ini dapat penulis kategorikan sebagai pre-test untuk mereka. Sehingga dapat disimpulkan bahwa mereka belum memiliki pengetahuan mengenai bahasa Mandarin sama sekali.

\section{Langkah Pelaksanaan}

Kegiatan dilakukan dengan memberikan materi bahasa Mandarin dasar, seperti pengucapan hanyu pinyin, pengucapan salam sehari-hari, hobi, hewan, dan pengenalan aksara hanzi beserta asal usulnya. Kemudian penulis juga membuatkan nama Mandarin untuk anakanak peserta ajar. Lalu untuk pengenalan budaya, penulis menceritakan nilai-nilai moral Tiongkok dan perayaan imlek di Tiongkok, selain itu juga memperkenalkan kehidupan Tiongkok modern kepada para peserta ajar

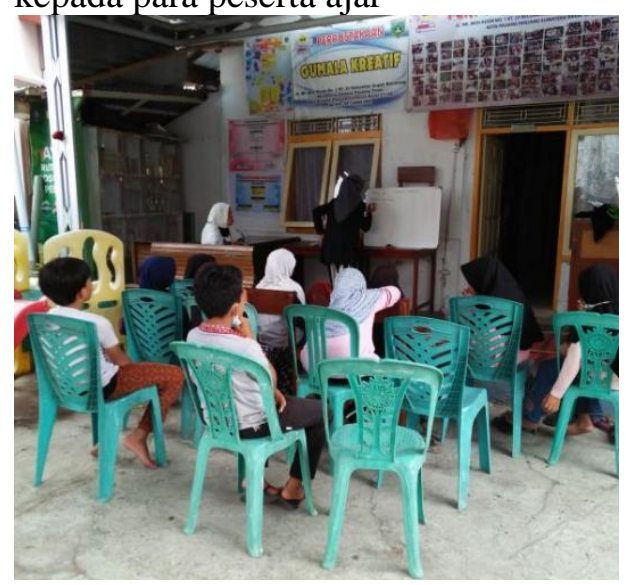

Gambar 1. Peserta ajar KKN-DR di TBM Gumala Kreatif

\section{HASIL DAN PEMBAHASAN}

Hasil dari kegiatan mengajar Bahasa Mandarin dan Kebudayaan Tiongkok diuraikan sebagai berikut.

\section{Hasil pembelajaran pelafalan huruf vokal dan konsonan hanyu pinyin}

Kegiatan ini dilaksanakan pada hari Jum'at, 5 Februari 2021. Pada kegiatan ini, penulis membawa alat peraga berupa poster yang berisikan huruf vokal dan konsonan hanyu pinyin. Peserta yang mengikuti pembelajaran berjumlah 23 orang. Pertama-tama penulis menjelaskan huruf vokal dalam bahasa Mandarin yang berjumlah 6, yaitu a, e, i, o, u, dan ü. Lalu penulis mencontohkan cara baca huruf tersebut dan meminta peserta mengulang kembali. Pertama-tama, semua peserta tidak bisa sama sekali membaca huruf vokal dengan benar. Saat membaca huruf vokal 'a', 'i', 'o' dan ' $u$ ' peserta tidak terlalu mengalami kesulitan, namun saat membaca huruf vokal 'e' dan 'ü' peserta merasa kesulitan, karena huruf 'e' dalam Bahasa Mandarin berbeda pengucapannya dengan huruf ' $\mathrm{e}$ ' dalam Bahasa Indonesia, sedangkan huruf 'ü' adalah huruf vokal yang asing bagi mereka. Selain itu saat mengajarkan huruf vokal gabungan, peserta juga merasa kesulitan, seperti 'ou', 'iu', 'ue', dan 'üe'. Saat mengajarkan huruf-huruf tersebut, penulis perlu mengulangi contoh pembacaan dan mempersilahkan mereka untuk mengikuti. Setelah diulang sebanyak 5 kali, sekitar $80 \%$ 
atau 18 orang dari 23 peserta bisa membaca huruf tersebut dengan benar. Untuk huruf konsonan, sebagian huruf bisa diucapkan dengan baik, sedangkan huruf seperti ' $j$ ', ' $q$ ', ' $x$ ', ' $z$ ', 'zh', 'c', 'ch', 's', 'sh', dan 'r' membutuhkan berkali-kali pengulangan dan hasil akhirnya sekitar 18 peserta atau $80 \%$ yang bisa melafalkannya dengan baik.

Pada saat mengajar materi ini, antusias peserta sangat tinggi karena ini adalah hari pertama penulis mengajar Bahasa Mandarin, dan peserta juga merasa huruf-huruf Mandarin sangat menarik untuk dipelajari.

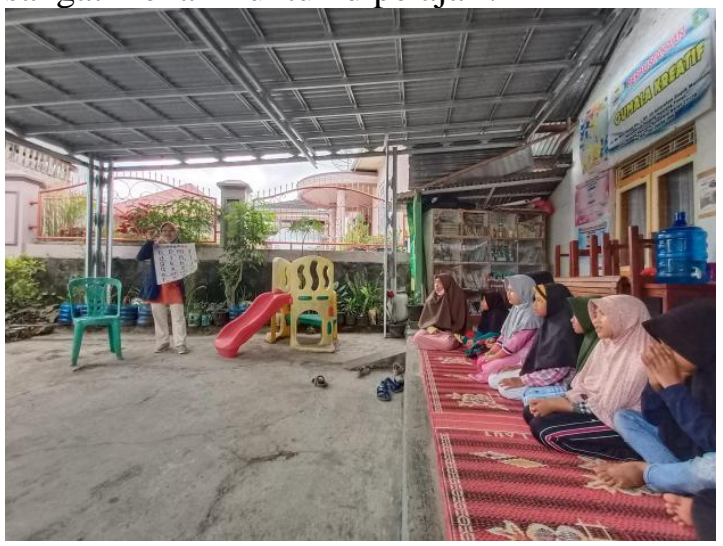

Gambar 2. Pembelajaran huruf vokal dan konsonan hanyu pinyin

\section{Hasil pengenalan hanzi dasar}

Hanzi adalah hal baru bagi anak-anak di TBM Gumala Kreatif. Pada materi ini, penulis pada awalnya menceritakan sejarah aksara hanzi kepada para peserta. Lalu menuliskan aksaraaksara dasar piktograf yang memiliki bentuk hanzi yang sama dengan bentuk benda aslinya, seperti 日 rì (matahari), 月 yuè (bulan), 口 kǒu (mulut), 山 shān (gunung), 川 chuān (sungai), 水 shuı̌ (air), 火 huǒ (api), 上 shàng (atas), 下 xià (bawah), 石 shí (batu), 大 dà (besar), 小 xiǎo (kecil) dan lain-lain. Penulis juga menjelaskan makna dari tiap-tiap hanzi. Peserta tertarik dengan materi ini karena sebelumnya belum pernah mengetahui bahwa aksara Mandarin ternyata memiliki filsafat yang dalam. Setelah selesai mengajar, penulis menguji pemahaman peserta terhadap materi. Penulis menyebutkan arti dalam Bahasa Indonesia dan meminta para peserta untuk menunjukkan hanzi-nya, hasilnya dari 10 orang peserta, semuanya (100\%) dapat menjawab pertanyaan dengan benar.

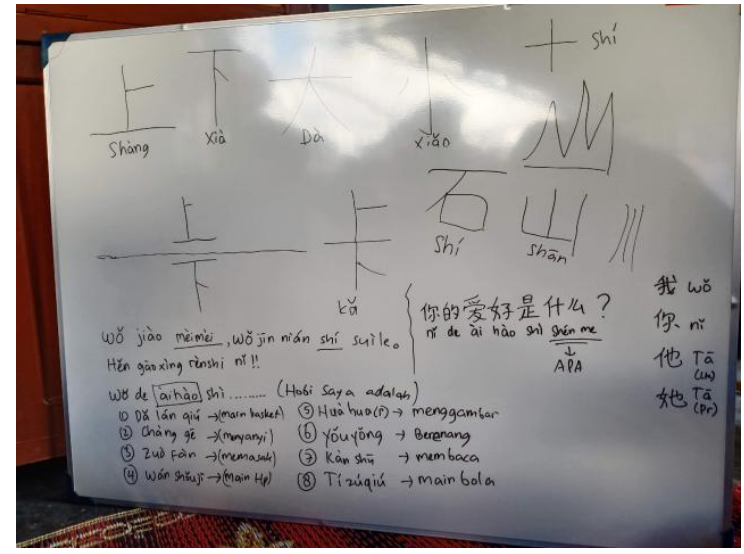

Gambar 3. Materi hanzi dan hobi

\section{Hasil pembelajaran mengenai hobi}

Setelah mengajarkan hanzi, penulis memberikan materi hobi kepada peserta. Hobi yang dipelajari adalah jenis-jenis hobi sederhana yang dimiliki anak-anak. Contohnya seperti bermain bola kaki, menyanyi, memasak, menggambar, membaca buku dan lain-lain. Saat menuliskan materi, peserta juga meminta penulis untuk menuliskan aksara hanzi pada tiap-tiap hobi. Kemudian penulis mengajak peserta menyebutkan hobihobi tersebut dengan keras, penulis juga mengajarkan bagaimana menanyakan “你的爱 好是什么? Nǐ de àihào shì shénme?(apa hobi kamu?)" dalam Bahasa Mandarin dan cara menjawabnya dengan kalimat “我的爱好是... W ó de àihào sh ì... (hobi saya adalah...)”. Setelah mengulang sekitar 6-7 kali, peserta satu persatu diminta untuk menjawab hobinya dan menanyakan hobi teman-temannya dalam Bahasa Mandarin. Berdasarkan penilaian penulis, 7 dari 10 peserta dapat memahami soal dan menjawab pertanyaan dengan sangat baik, sedangkan 3 orang sisanya masih terbata-bata dalam menjawab.

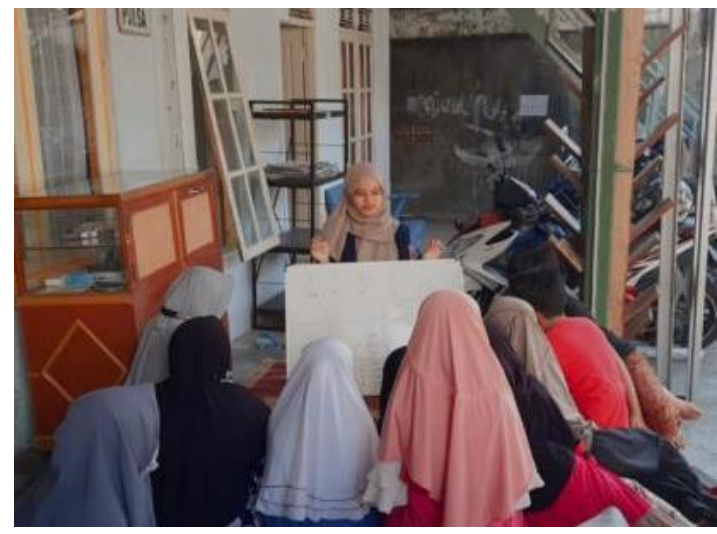

Gambar 4. Suasana belajar materi hobi 

pada Anak - Anak Taman Baca Masyarakat (TBM) Gumala Kreatif

\section{Hasil kegiatan pembuatan nama Mandarin peserta}

Dalam kegiatan ini, untuk menarik minat peserta dalam mempelajari bahasa Mandarin dan budaya Tiongkok, penulis memberitahu peserta bahwa setiap orang bisa mempunyai nama Mandarin yang memiliki arti dan menggambarkan diri masing-masing orang. Peserta pun tertarik dan menuliskan nama Indonesianya untuk penulis buatkan nama Mandarinnya. Penulis membuatkan nama Mandarin peserta berdasarkan kesamaan pelafalan suku kata nama Indonesia, kemudian mencari kata yang memiliki arti yang sesuai. Jumlah total peserta yang dibuatkan nama Mandarinnya ada 18 orang. Setelah mendapatkan nama Mandarin, reaksi semua peserta senang dan antusias dalam menanyakan arti namanya masing-masing. Setelah mencatat dan menghapalkan nama Mandarin, penulis menguji masing-masing peserta dengan meminta mereka untuk memperkenalkan diri menggunakan Bahasa Mandarin.

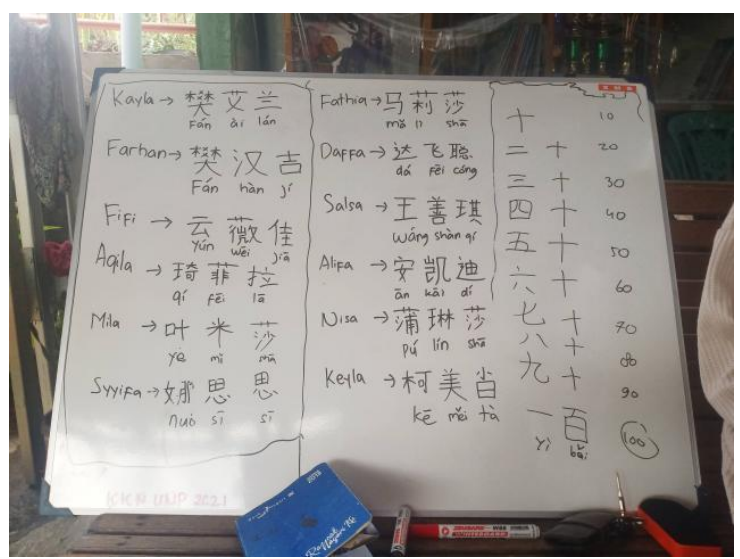

Gambar 5. Nama Mandarin peserta

\section{Hasil kegiatan pembelajaran warna dan hewan}

Di pertemuan terakhir, penulis memberikan materi pembelajaran mengenai warna dan hewan dalam bahasa Mandarin. Penulis meminta peserta menyebutkan warna kesukaannya masing-masing kemudian penulis menuliskannya dalam bahasa Mandarin. Penulis juga menuliskan cara menanyakan warna kesukaan dan meminta masing-masing peserta untuk menjawabnya.

Setelah itu peserta meminta penulis untuk mengajarkan nama-nama hewan dalam Bahasa Mandarin. Kemudian penulis dengan cara yang sama juga meminta peserta menyebutkan hewan kesukaannya dalam Bahasa Mandarin.

Pada akhir sesi, penulis menguji lagi pemahaman dan ketangkasan peserta dalam memahami materi. Penulis menanyakan satupersatu secara acak, dan hasil yang diperoleh adalah $85 \%$ atau 7 dari 9 peserta peserta dapat menjawab pertanyaan dengan benar dan lancar.

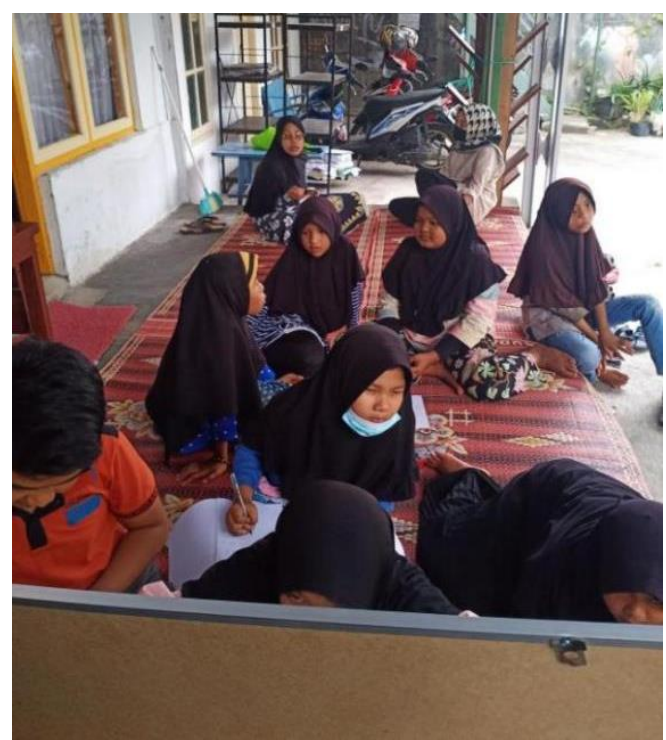

Gambar 6. Peserta mencatat materi pembelajaran

\section{Hasil pembelajaran mengenai perkenalan diri}

Materi perkenalan diri sudah penulis berikan semenjak pertemuan pertama dan selalu diulang hingga pertemuan akhir. Pada mulanya materi berupa penyebutan nama, umur dan salam, yaitu:

$$
\begin{aligned}
& \text { 你好, 我叫__, 我今年__岁了, 很高兴认识 } \\
& \text { 你。 } \\
& \text { Nǐ hăo, wǒ jiào__, wǒ jìnnián__suìle, hěn } \\
& \text { gàoxing rènshí nĭ. } \\
& \text { Halo, nama saya_, umur saya__tahun, senang } \\
& \text { berkenalan denganmu. }
\end{aligned}
$$

Pada awalnya peserta kesulitan menyebutkan paragraf perkenalan yang panjang. Lalu penulis memecah kalimat itu menjadi beberapa kata pendek dan meminta peserta mengulanginya. Perlahan peserta pun bisa menyebutkan dengan baik, hanya saja kalimat terakhir 很高兴认识你 hěn gāoxìng rènshí nǐ cukup sulit untuk dihafal para peserta. Pada pertemuan selanjutnya, penulis kembali membahas materi perkenalan diri.

\section{Evaluasi Pembelajaran Bahasa Mandarin}

Pada bagian ini penulis akan menjabarkan hasil evaluasi pembelajaran selama menjalani 
pengabdian masyarakat KKN-DR di kelurahan Guguk Malintang. Pada akhir pertemuan, penulis meminta peserta untuk berdiri satu persatu dan memperkenalkan diri. Untuk materi yang diujikan selain yang tertulis di atas, penulis juga menambahkan materi pembelajaran lainnya seperti hobi, warna kesukaan, dan hewan kesukaan, serta meminta peserta untuk memperkenalkan nama Mandarinnya masingmasing. Maka dari itu bagian ini penulis sebut sebagai tes akhir (post test) terhadap pemahaman peserta mengenai keseluruhan pembelajaran dalam kegiatan KKN-DR ini. Adapun format perkenalan dirinya adalah sebagai berikut:

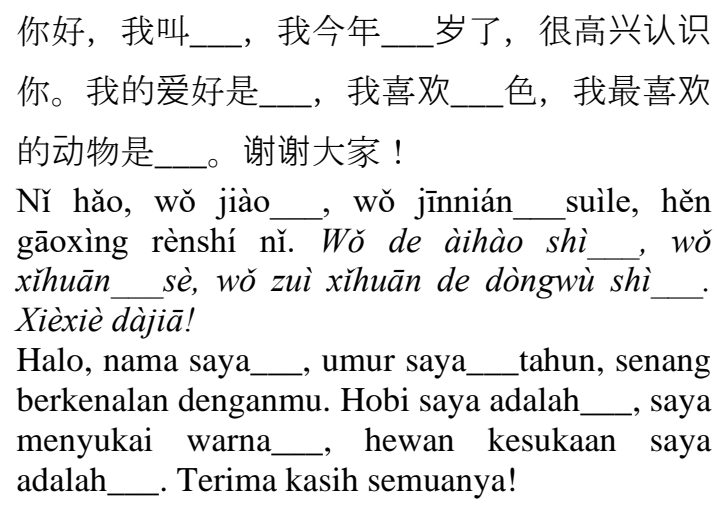

Hasil penilaian akhir akan dijabarkan dalam tabel berikut:

Tabel 1. Hasil penilaian akhir (post test) dari keseluruhan materi yang dinilai dari perkenalan diri

\begin{tabular}{lll}
\hline $\begin{array}{l}\text { Nama } \\
\text { peserta }\end{array}$ & $\begin{array}{l}\text { Kelancaran \& } \\
\text { keberanian } \\
\text { menjawab }\end{array}$ & $\begin{array}{l}\text { Kreativitas } \\
\text { jawaban }\end{array}$ \\
\hline Total nilai: & 100 & 100 \\
Peserta 1 & 88 & 90 \\
Peserta 2 & 80 & 82 \\
Peserta 3 & 88 & 91 \\
Peserta 4 & 88 & 92 \\
Peserta 5 & 89 & 93 \\
Peserta 6 & 85 & 92 \\
Peserta 7 & 85 & 85 \\
Peserta 8 & 84 & 80 \\
Peserta 9 & 90 & 90 \\
Peserta 10 & 80 & 82 \\
Rata-rata & 85,70 & 87,70
\end{tabular}

*Indikator penilaian diambil dari standar ujian HSKK (Hanyu Shuiping Kouyu Kaoshi). Mencakup pemahaman peserta terhadap pertanyaan, pelafalan, ketangkasan, dan sikap saat menjawab pertanyaan.

Dilihat dari nilai di atas, nilai rata-rata peserta adalah 85,70 untuk penilaian keberanian dan kelancaran menjawab, dan 87,70 untuk kreativitas jawaban. Jika dijumlahkan dan dibagi dua, rata-rata keduanya adalah 86,70, sehingga dapat disimpulkan pada sesi post test ini tingkat pemahaman peserta mencapai $86,7 \%$. Dari keseluruhan kegiatan pembelajaran bahasa Mandarin dan budaya Tiongkok, respon yang didapatkan sangat baik, dapat dilihat dari jumlah peserta yang datang selalu lebih dari 10 orang. Dan peserta juga tenang menyimak pemberian materi dan aktif menanggapi apabila penulis memberikan pertanyaan kepada mereka.

Respon dari para penggiat pun juga sangat baik, selalu memberikan fasilitas yang memadai saat kegiatan berlangsung. Selain itu para penggiat beberapa kali juga ikut serta dalam kegiatan pembelajaran. Para pegiat mengatakan bahwa semenjak adanya program belajar Mandarin, para peserta semakin semangat untuk datang mengikuti kegiatan TBM Gumala Kreatif. Selain itu program ini juga dapat mendatangkan manfaat dan kebanggaan bagi Kelurahan Guguk Malintang.

\section{SIMPULAN DAN SARAN}

Berdasarkan kegiatan KKN yang telah penulis laksanakan di Kelurahan Guguk Malintang, kesimpulan dari hasil yang diperoleh adalah sekitar $85 \%$ anak mengerti akan materi yang disampaikan, dan sekitar $75 \%$ anak bisa mengulangi materi dengan lancar. Peningkatan kemampuan dari awalnya 0 (nol) menjadi nilai dan pemahaman yang lebih baik adalah sebuah kemajuan dari hasil pembelajaran ini dalam kegiatan ini.

Penulis menyadari bahwa pada kenyataannya masyarakat sangat membutuhkan peran mahasiswa dan tenaga pendidik untuk turun tangan membantu meningkatkan kualitas program-program di masyarakat, baik masyarakat yang tinggal di desa maupun di kota, semuanya perlu dibimbing, diarahkan dan dibina agar menjadi sumber daya manusia yang unggul dan mampu bersaing di masa modern. Kepekaan sosial juga dapat membantu mahasiswa untuk lebih mengenal lingkungannya, menyadari urgensi kebutuhan masyarakat dan mempersiapkan program serta kontribusi yang terbaik untuk masyarakat.

Selama berkegiatan di Kelurahan Guguk Malintang, penulis semakin mengenal daerah tempat tinggal penulis sendiri, baik itu masyarakatnya serta potensi-potensi yang 
terdapat di dalamnya. Selain itu penulis juga semakin menyadari bahwa ilmu yang telah didapatkan di bangku perkuliahan sudah saatnya untuk diabdikan kepada masyarakat, untuk mengabdi kepada masyarakat dapat melihat ke lingkungan sekitar kita kemudian berkontribusi, hal tersebut sangat mulia dan bermanfaat bagi orang banyak.

Kegiatan pengajaran bahasa mandarin yang telah penulis laksanakan alhamdulillah mendapatkan sambutan yang luar biasa dari pihak kelurahan, penggiat dan peserta. Penulis juga melihat bakat yang terpendam dalam diri beberapa peserta, diharapkan peserta menyadari potensi diri mereka sehingga semakin berusaha lagi untuk belajar lebih banyak dan mengembangkan diri ke arah yang lebih baik, terutama bagi yang memiliki minat ke bidang bahasa, karena bahasa asing adalah kunci dalam berkomunikasi dengan masyarakat dunia.

Adapun saran yang dapat penulis berikan setelah melaksanakan kegiatan Kuliah Kerja Nyata (KKN) ini adalah agar masyarakat dapat meningkatkan kesadarannya untuk mengikuti kegiatan dan komunitas bermanfaat di lingkungan kelurahan. Semoga kita bisa bangkit bersama melalui kegiatan-kegiatan produktif meskipun masih berada dalam masa new normal ini.

\section{UCAPAN TERIMA KASIH}

Penulis berterima kasih kepada ibu Tri Budianingsih sebagai dosen pendamping lapangan kegiatan KKN, yang telah membimbing penulis sejak awal hingga akhir kegiatan. Kemudian penulis berterima kasih kepada pak lurah Kelurahan Guguk Malintang dan jajarannya serta masyarakat Kelurahan Guguk Malintang, yang telah mengizinkan penulis untuk melakukan kegiatan KKN di Kelurahan Guguk Malintang. Kemudian penulis ingin berterima kasih kepada ibu Yen, ibu Ris, ibu El dan ibu-ibu lainnya yang telah membimbing penulis dalam pelaksanaan KKN di lapangan. Semoga kebaikannya dibalas oleh Allah SWT, Aamiin YRA.

\section{DAFTAR PUSTAKA}

Dinas Kependudukan dan Pencatatan Sipil Kota Padang Panjang. (2020). Buku Aggregat Kependudukan Tahun 2020 (Data DKB Semester 1 Tahun 2020).

$\mathrm{Fu}$, Chunjiang. (2014). Origins of Chinese Language - Asal Usul Bahasa China. Jakarta: PT Elex Media Komputindo.

Sutami, Hermina. (2016). Fungsi dan Kedudukan Bahasa Mandarin di Indonesia. Paradigma, Jurnal Kajian Budaya. 2. 212. 10.17510/paradigma.v2i2.28.

Yesputra, Rolly. (2015). Pengabdian Kepada Masyarakat. Lembaga Penelitian dan Pengabdian Kepada Masyaraat STMIK Royal Kisaran. https://lppm.stmikroyal.ac.id/pengabdiankepada-masyarakat/. diakses pada 3 Mei 2021 14:20

Ying, Yi, dkk. (2013). Motivasi Belajar Bahasa Mandarin Sebagai Bahasa Kedua. Jurnal Binus University Vol. 4 No. 2 (2013): Humaniora

DOI: https://doi.org/10.21512/humaniora.v4i 2.3579 